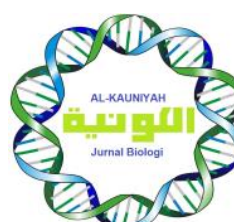

Available online at AL-KAUNIYAH: Jurnal Biologi

Website: http://journal.uinjkt.ac.id/index.php/kauniyah

AL-KAUNIYAH: Jurnal Biologi, 14(1), 2021, 42-51

\title{
IDENTIFIKASI POTENSI PERMUDAAN ALAM DI HUTAN RAWA GAMBUT TAMAN HUTAN RAYA ORANG KAYO HITAM PROVINSI JAMBI PASCA KEBAKARAN HUTAN
}

\author{
IDENTIFICATION OF SEEDLING POTENTIALS IN PEAT SWAMP FOREST \\ AT ORANG KAYO HITAM FOREST PARK JAMBI PROVINCE POST FOREST FIRE
}

Rike Puspitasari Tamin, Maria Ulfa, Zuhratus Saleh*

Fakultas Kehutanan Universitas Jambi, Jl. Raya Jambi-Ma.Bulian KM.15, Mendalo Indah, 36361 Muara Jambi

*Corresponding author: zuhratussaleh@ymail.com

Naskah Diterima: 30 Maret 2020; Direvisi: 3 Juli 2020; Disetujui: 7 Oktober 2020

\begin{abstract}
Abstrak
Regenerasi dan restorasi hutan rawa gambut merupakan hal yang sulit terjadi secara alami. Restorasi ekosistem bukan hanya membuat tegakan baru tetapi juga harus berbasis keanekaragaman hayati lokal untuk membuat peluang berhasilnya menjadi lebih tinggi. Tujuan dari penelitian ini adalah mendapatkan data mengenai potensi permudaan alam dalam rangka regenerasi dan restorasi lahan gambut di Tahura Orang Kayo Hitam pasca kebakaran hutan. Penelitian ini dilaksanakan selama 7 bulan, yaitu dari Maret sampai Oktober 2019 di Tahura Orang Kayo Hitam, Herbarium Fakultas Kehutanan Universitas Jambi dan Laboratorium Silvikultur dan Manajemen Universitas Jambi. Metode yang digunakan adalah kombinasi transek dengan garis berpetak. Hasil penelitian menunjukkan bahwa terdapat 29 jenis anakan alam yang tergabung dalam 19 famili tumbuhan. Jenis yang paling dominan adalah arang-arang (Diospyros mangiayi) diikuti oleh meranti bunga (Shorea teijsmanniana) dengan Indeks Nilai Penting (INP) berturut-turut sebesar $20,10 \%$ dan 19,33\%. Indeks kekayaan Margaleff $\mathrm{D}=4,88$, indeks keanekaragaman Shannon-Wiener H'= 2,96 dan indeks Evennes $E=0,88$. Nilai dari semua indeks menunjukkan kondisi permudaan alam yang cukup baik di Tahura Orang Kayo Hitam. Hal ini diharapkan mampu menjadi pendorong dalam restorasi ekosistem yang berbasis jenis lokal untuk masa depan hutan rawa gambut.
\end{abstract}

Kata kunci: Hutan rawa gambut; Permudaan alam; Regenerasi; Restorasi

Abstract

Regeneration and restoration of peat swamp forests is a difficult thing to happen naturally. Ecosystem regeneration and restoration not only create new stands but must also be based on local biodiversity to make the chances of success even higher. The purpose of this study is to obtain data and information about the potential of seedlings for the regeneration and restoration of peatlands in Tahura Orang Kayo Hitam after forest fires. This research was conducted for 7 months from March to October 2019 with locations in Orang Kayo Hitam Tahura, Herbarium of the Faculty of Forestry at the University of Jambi and the University of Jambi's Silviculture and Management Laboratory. The most dominant types are arang-arang (Diospyros mangiayi) followed by meranti bunga (Shorea teijsmanniana) with Important Value Index (INP) respectively of $20.10 \%$ and $19.33 \%$. Margaleff's Wealth Index D=4, 88. The Shannon-Wiener Diversity Index shows a value of $H$ 'of 2.96 and the Index of Evennes indicates a value of $E=0.88$. The values obtained from all of the measured indices indicate the condition of natural regeneration which is quite good in Tahura Orang Kayo Hitam. This is expected to lead to local species-based ecosystem restoration for the future of peat swamp forests.

Keywords: Peat swamp forest; Regeneration, Restoration; Seedlings

Permalink/DOI: http://dx.doi.org/10.15408/kauniyah.v14i1.15136 


\section{PENDAHULUAN}

Hutan rawa gambut di Indonesia termasuk yang paling luas di dunia dengan luas sekitar $200.000 \mathrm{~km}^{2}$ (Page, Rieley, \& Banks, 2011) tapi terdegradasi dengan cepat, karena hal-hal seperti kebakaran, logging, dan pertanian, sehingga pada tahun 2010 hanya 4\% hutan rawa gambut di Sumatra dan Kalimantan yang dapat dikatakan dalam kondisi yang sangat baik (Miettinen \& Liew 2010). Hutan rawa gambut merupakan ekosistem yang mempunyai keanekaragaman jenis pohon yang cukup tinggi sekitar 1.300-1.500 jenis walaupun banyak faktor pembatas, seperti keasaman serta kadar nutrien yang rendah (Posa, Wijedasa, \& Corlett, 2011; Giesen, Wijedasa, \& Page, 2018). Degradasi hutan rawa gambut di Indonesia menjadi hal yang menarik perhatian dunia. Kebakaran pada hutan rawa gambut akan melepas karbon dalam jumlah yang besar ke atmosfer (Miettinen, Hooijer, Vernimmen, Liew, \& Page, 2017), menghilangkan keanekaragaman hayati di dalamnya (Hoscilo, Page, Tansey, \& Riley, 2011) serta asap yang merusak bagi manusia yang terdampak di sekitarnya (Awaludin, 2016; Wulan \& Subagio, 2016). Hal ini kemudian semakin menguatkan usaha untuk melakukan restorasi kawasan hutan rawa gambut, dan menghindari hal yang dapat menimbulkan resiko kebakaran serta degradasi lainnya.

Taman Hutan Raya Orang Kayo Hitam (Tahura OKH) merupakan salah satu kawasan konservasi di Provinsi Jambi. Tahura OKH berlokasi secara administratif di Kabupaten Muaro Jambi dan Kabupaten Tanjung Jabung Timur. Kawasan Tahura ini didominasi oleh lahan gambut yang sangat rentan dan mudah terbakar. Luasnya $18.363,79$ ha, dan setelah kebakaran besar tahun 2015 lebih dari $70 \%$ arealnya menjadi daerah terbuka, sementara sisanya areal berhutan yang selamat dari kebakaran. Kebutuhan restorasi lahan gambut semakin meningkat terutama karena kebakaran hutan di kawasan ini terjadi hampir setiap tahun dan yang terakhir terjadi pada tahun 2019. Sampai saat ini berbagai usaha telah dilakukan dalam melakukan restorasi tetapi sebagian besar terkendala dalam menemukan jenis yang sesuai, dan mahalnya biaya dalam usaha revegetasi sebagai bagian dalam usaha restorasi tersebut.

Permasalahan suksesi buatan melalui usaha restorasi adalah seringkali jenis yang ditanam bukanlah jenis yang berasal dari habitat sekitar sebelum terjadi degradasi. Jenisjenis seperti jelutung rawa dan pulai rawa hampir selalu menjadi primadona restorasi lahan gambut. Padahal restorasi bukan hanya membuat tegakan baru tetapi juga harus berbasis keanekaragaman hayati lokal untuk membut peluang berhasilnya menjadi lebih tinggi (Dobson, Bradshaw, \& Baker, 1997). Dalam rangka menjamin kesuksesan proses restorasi, sangat penting dilakukan usaha agar regenerasi alami terjadi dengan lebih baik terutama pada jenis dominan di ekosistem tersebut (Pickup, Wilson, Freudenberger, Nicholls, \& Gould, 2013). Pemahaman yang baik terhadap proses regenerasi alami akan membantu proses restorasi, terutama dalam hal menekan biaya, bahkan juga sangat penting artinya dalam perencanaan dan manejemen kawasan hutan (Liira, Sepp, \& Kohv 2011). Benih dan pohon induk yang berasal dari lokasi yang paling dekat dengan lokasi yang akan direstorasi merupakan salah satu cara yang dapat ditempuh dalam mempercepat dan mempermudah proses restorasi. Pemilihan jenis yang akan ditanam dalam rangka rehabilitasi hutan bekas terbakar idealnya mengacu pada jenis tumbuhan yang ada di lokasi itu sebelumnya. Jenis pohon asli hutan gambut (indigenous tree species) sangat dianjurkan untuk digunakan dalam kegiatan rehabilitasi lahan gambut karena mampu beradaptasi dengan baik pada areal bergambut (Angraini, 2013).

Pemilihan bibit jenis lokal menjadi penting dalam kegiatan restorasi kawasan. Tamin, Ulfa, dan Saleh (2019) telah mengidentifikasi potensi pohon induk yang ada di lokasi Tahura OKH ini dan menemukan setidaknya 25 jenis dan 52 individu pohon, yang sebagiannya merupakan pohon induk potensial. Hasil penelitian tersebut sangat membantu dalam memahami bagaimana regenerasi alami dapat terjadi di lokasi tersebut. Selanjutnya penelitian kali ini bertujuan untuk melihat keanekaragaman dan struktur komunitas anakan pohon yang tumbuh alami di Tahura $\mathrm{OKH}$ dalam rangka 
mengidentifikasi potensinya sebagai sumber benih untuk restorasi hutan rawa gambut yang murah secara biaya.

\section{MATERIAL DAN METODE}

Penelitian ini dilaksanakan selama 7 bulan, dari Maret sampai Oktober 2019 dan dilakukan di Taman Hutan Raya Orang Kayu Hitam Provinsi Jambi (Gambar 1), Laboratorium Silvikultur dan Manajemen Fakultas Kehutanan Universitas Jambi dan Herbarium Fakultas Kehutanan Universitas
Jambi. Alat yang digunakan dalam penelitian ini adalah gunting stek, plastik, kertas label, benang wol, pensil, kertas koran, galah, $\mathrm{pH}$ meter, higrometer, global positioning system (GPS), kamera, tali rafia, pita ukur, kantong sampel tanah serta alat tulis, dan seperangkat komputer. Adapun bahan yang digunakan dalam pengumpulan sampel, yaitu tally sheet, material yang memiliki ciri khas, seperti buah, biji dan lainnya, polybag, tanah topsoil, pasir, kompos, dan alkohol $70 \%$.

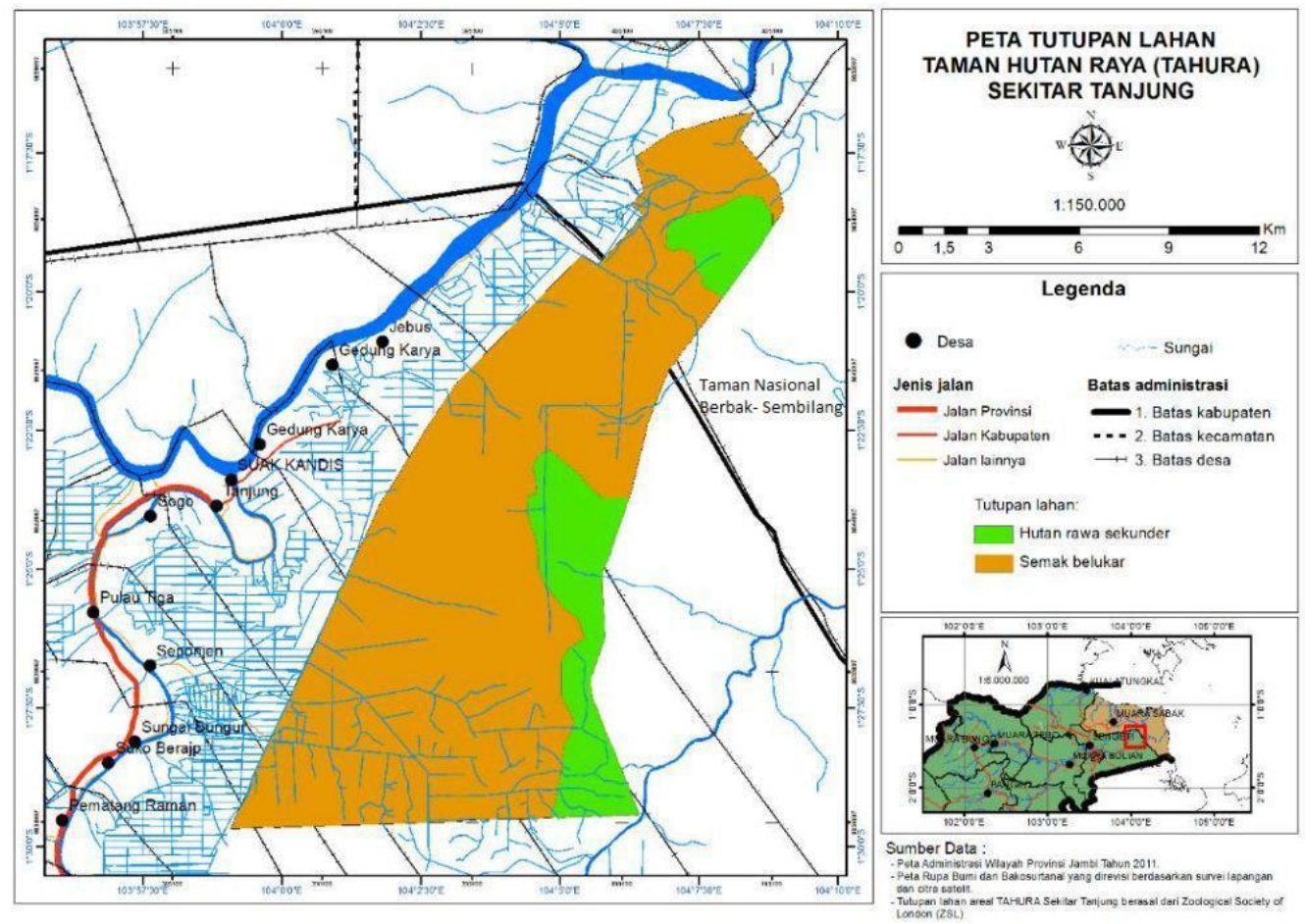

Gambar 1. Peta Taman Hutan Raya Sekitar Tanjung/Orang Kayo Hitam (Tamin et al., 2019)

Pengambilan sampel di lapangan dengan menggunakan metode survei, yaitu kombinasi jalur dan petak. Cara peletakan unit contohnya menggunakan cara sistematik dengan posisi $150 \mathrm{~m}$ ke arah hutan dan $150 \mathrm{~m}$ ke arah luar hutan, yang titik awalnya adalah tepi hutan, sehingga satu jalur akan memuat 6 plot pengamatan dengan panjang $300 \mathrm{~m}$ dan dilakukan sebanyak 3 jalur. Plot pengamatan berukuran 20 × $20 \mathrm{~m}$ (Gambar 2) sedangkan pengamatan anakan pohon dilakukan pada plot berukuran 2 × 2 m yang diletakkan pada setiap sudut plot pengamatan, sehingga setelah dilakukan pembuatan plot-plot penelitian berjumlah 72 buah. Anakan pohon yang dihitung adalah semua anakan mulai level seedling (tinggi $\leq 1,5 \mathrm{~m}$ ) sampai sampling yang diameternya kurang dari $5 \mathrm{~cm}$ (Yang, Yan, \& Liu, 2014). Semua individu yang masuk kategori tersebut dicatat ke tally sheet dilengkapi yang dengan nama lokal dan nama ilmiah. Jenis yang bisa dikenali secara langsung dicari nama ilmiahnya dengan buku panduan Putra, Manuri, Hariyanto, dan Sibaragiang (2011). Jika buku panduan tidak mencukupi, spesimen diidentifikasi melalui foto yang diambil secara akurat, dan jika tidak berhasil juga, sampel dikirimkan ke lembaga yang berkompeten melakukan identifikasi nama ilmiah. Setelah dilakukan analisis data untuk mendapatkan nilai Indeks Nilai Penting (INP), dilanjutkan dengan analisis data menghitung indeks kekayaan Margaleff, indeks keanekaragaman Shannon-Wiener, dan indeks kemerataan Shannon-Wiener (Mawazin \& Subiakto, 2013). Skala tinggi, sedang dan rendah untuk indeks kekayaan Margaleff, indeks keanekaragaman Shannon-Wiener dan 
indeks kemerataan Shannon-Wiener mengacu

kepada Magurran (2013).

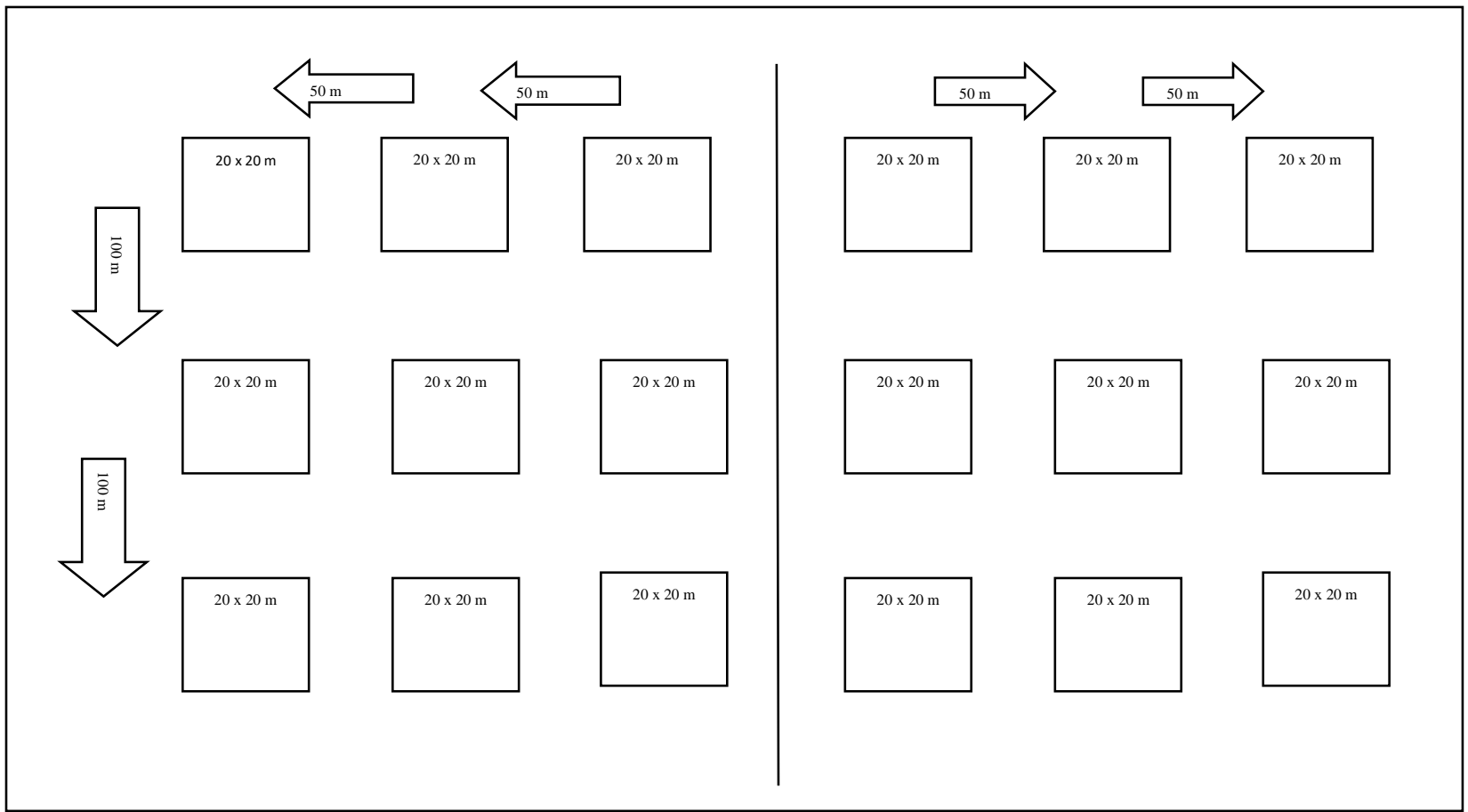

Gambar 2. Skema plot penelitian

Keterangan: $\longrightarrow=$ arah rintis kedalam hutan (belum terbakar)

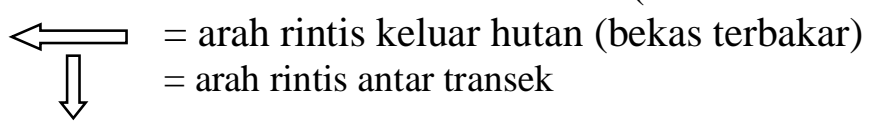

HASIL

Pada lokasi penelitian terlihat jelas perbedaan tegakan vegetasi antara bekas terbakar dan tegakan yang tidak terbakar (Gambar 3). Vegetasi yang tidak terbakar ditandai dengan masih dijumpainya berbagai pohon dengan diameter lebih dari $30 \mathrm{~cm}$, sedangkan vegetasi bekas terbakar ditandai dengan dominannya tumbuhan pionir seperti paku-pakuan dan ilalang.

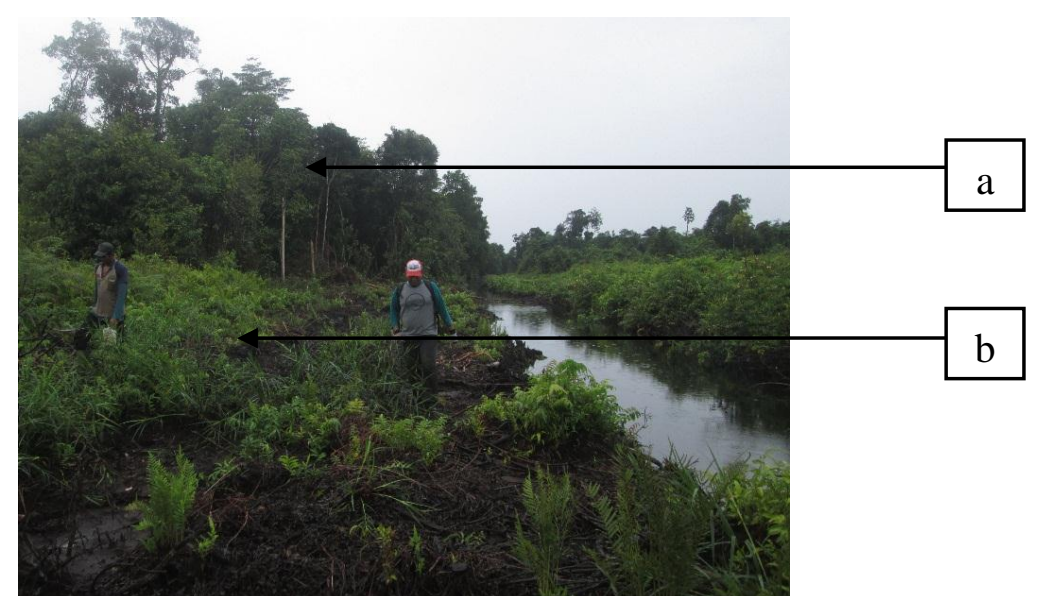

Gambar 3. Batas antara vegetasi tegakan tinggal dan lahan bekas terbakar di Tahura Orang Kayo Hitam. Vegetasi tegakan tinggal/ hutan (a) dan lahan bekas kebakaran (b)

Berdasarkan hasil identifikasi diperoleh 29 jenis tumbuhan (pohon) yang terdiri atas 19 famili tumbuhan (Tabel 1). Jenis yang paling banyak ditemukan berasal dari famili Dipterocarpaceae yaitu sebanyak 6 jenis, diikuti oleh famili Anacardiaceae yaitu sebanyak 3 jenis. Selanjutnya dilakukan penghitungan INP untuk melihat struktur vegetasi permudaan alam yang ditemukan dalam lokasi penelitian. 
Tabel 1. Hasil identifikasi permudaan alam yang ditemukan pada lokasi penelitian

\begin{tabular}{|c|c|c|c|c|c|c|}
\hline No. & Famili & Jenis & Nama lokal & $\mathrm{KR}(\%)$ & $\mathrm{FR}(\%)$ & [NP $(\%)$ \\
\hline \multirow[t]{4}{*}{1.} & Anacardiaceae & Gluta renghas & Rengas & 1,154 & 1,010 & 2,164 \\
\hline & & Mangifera & Rengas & & & \\
\hline & & quadrifida & sumpung & 0,769 & 1,010 & 1,779 \\
\hline & & $\begin{array}{l}\text { Melanorrhea } \\
\text { wallichii }\end{array}$ & Pelakok & 3,846 & 4,040 & 7,887 \\
\hline \multirow[t]{2}{*}{2.} & Annonaceae & $\begin{array}{l}\text { Drepananthus } \\
\text { biovulatus }\end{array}$ & Pisang-pisang & 9,231 & 8,081 & 17,312 \\
\hline & & Xylopia altisima Bl. & Jangkang & 0,769 & 1,010 & 1,779 \\
\hline 3. & Apocynaceae & Dyera lowii & Jelutong & 3,462 & 4,040 & 7,502 \\
\hline 4. & Clusiaceae & Callophyllum sp. & Bintangur & 1,154 & 1,010 & 2,164 \\
\hline 5. & Dilleniaceae & Dillenia eximia & Simpur & 1,538 & 1,010 & 2,549 \\
\hline \multirow[t]{7}{*}{6.} & Dipterocarpaceae & Anisoptera sp. & Mersawa & 2,692 & 4,040 & 6,733 \\
\hline & & Shorea ovata & Merawan & 0,769 & 1,010 & 1,779 \\
\hline & & Shorea & Meranti & & & \\
\hline & & palembanica & lempung & 1,154 & 1,010 & 2,164 \\
\hline & & Shorea sp. & Meranti & 3,077 & 3,030 & 6,107 \\
\hline & & Shorea sp1 & Meranti batu & 10,385 & 9,091 & 19,476 \\
\hline & & $\begin{array}{l}\text { Shorea } \\
\text { teysmanniana }\end{array}$ & Meranti bunga & 9,615 & 10,101 & 19,716 \\
\hline 7. & Ebenaceae & $\begin{array}{l}\text { Diospyros } \\
\text { mangiayi }\end{array}$ & Arang-arang & 10,385 & 10,101 & 20,486 \\
\hline 8. & Elaeocarpaceae & $\begin{array}{l}\text { Elaeocarpus } \\
\text { griffithi }\end{array}$ & Kelat merah & 4,231 & 3,030 & 7,261 \\
\hline 9. & Euphorbiaceae & Baccaurea sp. & Asam-asam & 0,769 & 1,010 & 1,779 \\
\hline 10. & Fabaceae & $\begin{array}{l}\text { Archidendron } \\
\text { fagifolium }\end{array}$ & Kayu pagar & 3,846 & 3,030 & 6,876 \\
\hline 11. & Hypericaceae & $\begin{array}{l}\text { Cratoxylon } \\
\text { arborescens }\end{array}$ & Gerunggang & 0,769 & 1,010 & 1,779 \\
\hline \multirow[t]{2}{*}{12.} & Lauraceae & Alseodaphne sp. & Medang lendir & 1,538 & 1,010 & 2,549 \\
\hline & & Litsea $\mathrm{sp}$ & Medang & 3,462 & 4,040 & 7,502 \\
\hline 13. & Loganiaceae & Fagraea gigantea & Bulian kasang & 0,769 & 1,010 & 1,779 \\
\hline 14. & Moraceae & Ficus hispida & Aro & 3,077 & 6,061 & 9,138 \\
\hline 15. & Myristicaceae & Knema cinerea & Darah-darah & 1,154 & 1,010 & 2,164 \\
\hline \multirow[t]{2}{*}{16.} & Myrtaceae & Syzygium littoralis & Kelat putih & 0,385 & 1,010 & 1,395 \\
\hline & & Syzygium sp. & Kelat & 7,692 & 7,071 & 14,763 \\
\hline 17. & Rutaceae & $\begin{array}{l}\text { Melicope lunu- } \\
\text { ankenda }\end{array}$ & Melicope & 9,615 & 8,081 & 17,696 \\
\hline 18. & Sapotaceae & Palaquium sp. & Nyato babi & 0,769 & 1,010 & 1,779 \\
\hline 19. & Tetrameristaceae/Theaceae & $\begin{array}{l}\text { Tetramerista } \\
\text { glabra }\end{array}$ & Punak & 1,923 & 2,020 & 3,943 \\
\hline Total & 19 famili & 29 jenis & & 100 & 100 & 200 \\
\hline
\end{tabular}

Pada Tabel 1 terlihat bahwa arang-arang (Diospyros sp.) memiliki nilai INP tertinggi dibandingkan dengan 28 jenis lainnya, dengan nilai $20,49 \%$ diikuti jenis dari famili Dipterocarpaceae, yaitu meranti bunga dan meranti batu dengan nilai $19,72 \%$ dan $19,48 \%$.
Hasil analisis menunjukkan nilai $\mathrm{H}^{\prime}$ sebesar 2,96. Indeks keanekaragaman ShannonWiener $\left(\mathrm{H}^{\prime}\right)$, indeks kekayaan Margaleff (D) dan indeks kemerataan Shannon-Wiener (E) ditampilkan pada Tabel 2. Hasil analisis data menunjukkan nilai $\mathrm{D}=4,88$. Nilai ini 
menunjukkan kekayaan jenis anakan alam pada lokasi penelitian terbilang tinggi. Selanjutnya Indeks Evennes (kemerataan) menunjukkan nilai $\mathrm{E}=0,88$. Nilai ini juga menunjukkan tingkat kemerataan jenis di lokasi penelitian yang tinggi.

Tabel 2. Indeks kekayaan, indeks keanekaragaman, dan indeks kemerataan

\begin{tabular}{lcc}
\hline \multicolumn{1}{c}{ Indeks } & Nilai & Keterangan \\
\hline Indeks Kekayaan Margaleff (D) & 4,88 & Tinggi \\
Indeks Keanekaragaman Shannon-Wiener $\left(\mathrm{H}^{\prime}\right)$ & 2,96 & Sedang \\
Indeks Kemerataan Shannon-Wiener $(\mathrm{E})$ & 0,88 & Tinggi \\
\hline
\end{tabular}

\section{PEMBAHASAN}

Kebakaran Tahura OKH sekitar bulan September tahun 2015 menghabiskan tutupan lahan hutan rawa gambut sekunder yang berbatasan dengan lahan milik masyarakat dan perkebunan sawit. Kebakaran ini menyisakan tutupan lahan hutan rawa gambut sekunder seluas 2.109,5 ha di arah timur kawasan Tahura yang berbatasan langsung dengan Taman Nasional Berbak-Sembilang. Kebakaran ini juga memusnahkan tanaman jelutung rawa yang telah ditanam saat kegiatan rehabilitasi kawasan. Kondisi Tahura OKH pada saat penelitian, gambut tergenang air, seluas mata memandang hanya puing-puing kayu atau pohon yang terbakar, tumbuhan pionir hasil suksesi seperti paku-pakuan, dan teki-tekian. Kondisi Tahura $\mathrm{OKH}$ saat ini merupakan bentuk nyata dari hutan rawa gambut yang terdegradasi tetapi masih punya tegakan vegetasi hutan yang selamat dari kebakaran. Kondisi terdegradasi tersebut ditunjukkan dengan dominasi formasi belukar sebagai pionir akibat kebakaran hutan (Tamin, Ulfa, \& Saleh, 2018). Pada vegetasi ini masih terdapat berbagai pohon asli ekosistem hutan rawa gambut bahkan sebagiannya sudah diteliti dan berpotensi sebagai pohon induk untuk kebutuhan bibit restorasi (Tamin et al., 2019). Berbagai jenis yang ditemukan dalam penelitian ini (Tabel 1) juga ditemukan oleh Tamin et al. (2019). Munculnya permudaan alam dengan kerapatan jenis yang cukup tinggi dan adanya pohon dewasa dengan status pohon induk dari jenis yang sama menunjukkan proses regenerasi di Tahura OKH berlangsung dengan cukup baik (Khaine et al., 2018). Secara umum ekosistem hutan rawa gambut di Asia Tenggara memiliki keanekaragaman jenis yang tinggi (Giesen et al., 2018) bahkan setelah terjadinya regenerasi pasca degradasi hutan rawa gambut, karena sebab-sebab seperti kebakaran berulang dan usaha hutan tanaman (Wijedasa et al., 2020).

Jenis-jenis yang didapatkan dalam penelitian ini (Tabel 1) merupakan jenis yang biasa terdapat di hutan rawa gambut baik ekosistem asli yang belum terdegradasi, maupun yang sudah terdegradasi. Hal ini terlihat saat membandingkan Tabel 1 dengan beberapa penelitian serupa seperti penelitian Mawazin dan Subiakto (2013), Blackham, Webb, dan Corlett (2014), Rachmanadi, Faridah, Sumardi, dan Van der Meer (2017), serta Wijedasa et al. (2020). Beberapa jenis dari famili Myrtaceae dan Dipterocarpaceae selalu muncul, dan mengindikasikan beberapa jenis dari famili tersebut merupakan sumber anakan bagi regenerasi pohon pada hutan rawa gambut terdegradasi di lokasi penelitian. Beberapa jenis dengan INP paling tinggi pada penelitian ini juga merupakan jenis yang biasa ditemukan pada hutan rawa gambut. Arangarang (Diospyros sp.) yang merupakan jenis dengan INP tertinggi pada penelitian ini juga ditemukan dalam penelitian sebelumnya yaitu pada penelitian Putra et al. (2011). Meranti bunga dan meranti batu (Shorea spp.) yang nilai INPnya tepat di bawah arang-arang merupakan anggota dari famili Dipterocarpaceae yang memang sudah terekam punya kemampuan regenerasi yang baik di hutan gambut, terutama karena pemencaran bijinya yang dibantu oleh angin (Blackham et al., 2014; Wijedasa et al., 2020). Melicope (Melicope lunu-ankenda) merupakan jenis yang biasa ditemukan pada hutan rawa gambut terdegradasi yang telah mulai melakukan regenerasi pada tahap awal (Blackham et al., 2014). Komposisi jenis pohon cenderung berubah pada daerah yang mengalami gangguan dan semakin bagus regenerasinya pada daerah yang tidak punya gangguan bahkan bisa saja terdapat jenis baru 
yang belum pernah tercatat di daerah tersebut (Jayakumar \& Nair, 2013).

Di hutan tropis, keanekaragaman jenis pohon ditentukan oleh beberapa hal, yaitu parameter habitat mikro, tingkat gangguan, dan geografi wilayah. Regenerasi alami di hutan tropis merupakan sebuah proses yang kompleks namun masih dapat dilihat potensi permudaan alamnya, yaitu bagian yang dilihat adalah kerapatan dan frekuensi (Smith, Larson, Kelty, \& Ashton, 1997). Kerapatan didefinisikan sebagai jumlah individu suatu jenis dibagi dengan satuan luas, sedangkan frekuensi diartikan sebagai jumlah perjumpaan suatu jenis dalam plot pengamatan dibagi dengan jumlah plot keseluruhan. Kerapatan suatu jenis dalam vegetasi biasanya berkorelasi negatif dengan beberapa faktor di sekitarnya, seperti lapisan serasah dan kanopi hutan terutama tumbuhan herba dan semak, namun berkorelasi positif dengan kanopi pohon (Yang et al., 2014). Hal ini menunjukkan bahwa kerapatan permudaan akan berkurang jika kerapatan semak dan herba meningkat. Penyebab terjadinya fenomena ini diduga karena adanya persaingan terutama terhadap unsur hara dan matahari yang biasanya menyebabkan kurangnya panjang akar atau tinggi yang tidak ideal bagi permudaan alam (Harmer, Kiewitt, \& Morgan, 2012; Bailey, Davidson, \& Close, 2012).

Nilai INP yang ditunjukkan pada Tabel 1 merupakan nilai yang didapat dari penjumlahan kerapatan relatif (KR) ditambah dengan frekuensi relatif (FR) karena penelitian ini tidak mengukur basal area untuk mendapatkan nilai dominansi. Biasanya INP yang ditampilkan merupakan penjumlahan KR $+\mathrm{FR}+\mathrm{DR}$ (Dominansi Relatif) (Indriyanto, 2006). INP juga merupakan indikasi dominasi suatu jenis secara umum di lokasi penelitian (Das, Alam, \& Hossain, 2018). Pada 5 jenis yang memiliki INP tertinggi di penelitian ini terlihat bahwa kombinasi INP lima jenis tersebut mencapai $46 \%$ dari total INP semua jenis permudaan alam yang terdata dalam penelitian ini. Jenis-jenis yang dominan ini berhasil melakukan proses regenerasi yang diduga terjadi karena cara penyebaran benihnya terjadi lewat bantuan angin dan atau burung sampai menyebar ke lokasi yang berada pada batas hutan yang sudah terbakar (Wijedasa et al., 2020).

Indeks-indeks yang diukur dalam penelitian ini secara umum menunjukkan potensi regenerasi alami yang terjadi di Tahura OKH. Indeks yang dihitung dan dianalisis ini juga merupakan bagian dari usaha untuk mendapatkan kondisi keanekaragaman secara utuh pada suatu kawasan hutan (Rahman, Rahman, \& Chowdhury, 2019). Indeks kekayaan jenis, indeks keanekaragaman, dan indeks kemerataan merupakan indikator bagi keseimbangan ekosistem serta vegetasi di dalamnya (Odum, 1996). Indeks kekayaan jenis mampu menunjukkan banyaknya jenis dalam suatu komunitas yang akan bermanfaat dalam melihat potensi keanekaragaman ekosistem (Magurran, 2013). Khumbongmayun, Khan, dan Tripathi (2005) menambahkan bahwa kekayaan jenis merupakan salah satu unsur penting yang harus diperhatikan dalam manajemen kawasan konservasi seperti Tahura OKH ini. Sementara indeks keanekaragaman dan indeks kemerataan akan berpengaruh pada kestabilan suatu ekosistem (Indriyanto, 2006). Semakin tinggi nilai kedua indeks ini maka akan memperbesar peluang berhasilnya regenerasi alami yang terjadi di Tahura OKH. Proses regenerasi sendiri merupakan faktor yang harus diperhatikan dalam manajemen kawasan hutan secara umum karena pada proses regenerasi dapat dilihat berapa kekayaan jenis yang mampu bertahan dan perubahan yang mungkin terjadi (Duchok, Kent, Khumbongmayun, Paul, \& Khan, 2005).

Keberadaan permudaan alam di suatu lokasi menunjukkan terjadinya regenerasi dan suksesi pada suatu ekosistem. Pada kasus hutan rawa gambut yang terdegradasi, regenerasi alami sangat dibutuhkan dalam rangka restorasi ekosistem. Hal ini terjadi karena mahalnya biaya revegetasi di lapangan yang mencapai \pm 2.500 USD (Wibisono \& Dohong, 2017) serta terbatasnya ketersediaan bibit dari jenis lokal. Setelah penelitian Tamin et al. (2019) yang mengidentifikasi pohon induk potensial serta pada penelitian ini yang mendapatkan jenis permudaan alam yang tumbuh di hutan rawa gambut pasca kebakaran, maka idealnya harus dilakukan riset lebih lanjut untuk menggunakan jenis yang 
telah ditemukan untuk kebutuhan restorasi ekosistem. Selama ini usaha revegetasi hanya mengandalkan jenis yang telah diketahui daya tahannya di daerah rawa gambut, seperti Dyera polyphylla dan Shorea balangeran (Graham, Giesen, \& Page, 2016), sehingga mencari jenis baru yang tahan terhadap berbagai cekaman yang ada di hutan rawa gambut harus menjadi prioritas dalam usaha restorasi hutan rawa gambut (Giesen, 2015). Hasil penelitian ini digabungkan dengan penelitian sebelumnya, terutama Tamin et al. (2019), diharapkan mampu menjadi data dasar dalam usaha pembuatan nursery di desa sekitar Tahura OKH demi lancarnya kegiatan restorasi yang mudah, murah dan berkelanjutan.

\section{SIMPULAN DAN SARAN}

Pada penelitian ini diketahui bahwa terdapat 29 jenis dan 19 famili tumbuhan yang berada pada tingkat permudaan alam di Tahura OKH Provinsi Jambi. Analisis INP menunjukkan bahwa arang-arang merupakan jenis dengan INP tertinggi di lokasi penelitian disusul meranti batu, meranti bunga, Melicope, dan pisang-pisang. Pengukuran indeks kekayaan Margaleff menghasilkan $\mathrm{D}=4,88$ (tinggi), indeks keanekaragaman ShannonWiener menghasilkan nilai $\mathrm{H}^{\prime}=2,96$ (sedang), dan indeks evennes (kemerataan) menghasilkan nilai $\mathrm{E}=0,88$ (tinggi). Nilai yang didapatkan dari semua indeks yang diukur ini menunjukkan kondisi permudaan alam yang cukup baik di Tahura OKH. Untuk penelitian selanjutnya disarankan agar mengambil data guguran buah dan seed soil bank sehingga perhitungan regenerasi alami yang terjadi menjadi lebih komprehensif.

\section{UCAPAN TERIMA KASIH}

Terima kasih kepada pihak UPTD Tahura OKH yang memfasilitasi penelitian di lapangan, dan para mahasiswa Fakultas Kehutanan Universitas Jambi yang membantu jalannya penelitian ini. Penelitian ini berjalan dengan dana DIPA PNBP Lembaga Penelitian dan Pengabdian Masyarakat Skema Penelitian Dasar Unggulan Universitas Tahun Anggaran 2019 Nomor: SP DIPA-041.01.2.400950/2019 Tanggal 05 Desember 2018 sesuai dengan Surat Kontrak Penelitian Nomor: B/659/UN21.18/PT.01.03/2019 Tanggal 07 Mei 2019.

\section{REFERENSI}

Angraini, W. (2013). Rencana rehabilitasi hutan dan lahan kawasan bergambut wilayah kerja BPDASHL Indragiri Rokan. In A. P. Tampubolon (Ed.), Lokasi penanaman kembali, jumlah kebutuhan bibit dan skema penanaman berkelanjutan jenis ramin. Prosiding Workshop Nasional (pp. 3-18). Bogor, Indonesia.

Awaludin. (2016). Keluhan kesehatan masyarakat akibat kabut asap kebakaran hutan dan lahan di Kota Pekanbaru. Journal Endurance, 1(1), 37-46. doi: 10.22216/jen.v1i1.1079.

Bailey, T. G., Davidson, N. J., \& Close, D. C. (2012). Understanding the regeneration niche: Microsite attributes and recruitment of eucalypts in dry forests. Forest Ecology and Management, 269, 229-238.

doi: 10.1016/j.foreco.2011.12.021.

Blackham, G. V., Webb, E. L., \& Corlett, R. T. (2014). Natural regeneration in a degraded tropical peatland, Central Kalimantan, Indonesia: Implications for forest restoration. Forest Ecology and Management, 324, 8-15. doi: 10.1016/j.foreco.2014.03.041.

Das, S. C., Alam, M. S., \& Hossain, M. A. (2018). Diversity and structural composition of species in dipterocarp forests: A study from Fasiakhali Wildlife Sanctuary, Bangladesh. Journal of Forestry Research, 29(5), 1241-1249. doi: 10.1007/s11676-017-0548-7.

Dobson, A. P., Bradshaw, A. D., \& Baker, A. J. M. (1997). Hopes for the future: Restoration ecology and conservation biology. Science, 2(7), 515-522. doi: 10.1126/science.277.5325.515.

Duchok, R., Kent, K., Khumbongmaum, A. D., Paul, A., \& Khan, M. L. (2005). Population structure and regeneration status of medicinal tree Illicium griffithii in relation to disturbance gradients in temperate broad-leaved forest of Arunachal Pradesh. Current Science, 89(4), 673-676.

Giesen, W. (2015). Utilising non-timber forest products to conserve Indonesia's peat swamp forests and reduce carbon 
emissions. Journal of Indonesian Natural History, 3(2), 10-19.

Giesen, W., Wijedasa, L. S., \& Page, S. E. (2018). Unique Southeast Asian peat swamp forest habitats have relatively few distinctive plant species. Mires and Peat, 22(1), 1-13. doi: 10.19189/MaP.2017.OMB.287.

Graham, L. L. B., Giesen, W., \& Page, S. E. (2016). A common-sense approach to tropical peat swamp forest restoration in Southeast Asia. Restoration Ecology, 25(2), 312-321. doi: 10.1111/rec.12465.

Harmer, R., Kiewitt, A., \& Morgan, G. (2012) Effects of overstory retention on ash regeneration and bramble growth during conversion of a pine plantation to native broadleaved woodland. European Journal of Forest Research, 131(6), 1833-1843.

Hoscilo, A., Page, S. E., Tansey, K. J., \& Rieley, J. O., (2011). Effect of repeated fires on landcover change on peatland in Southern Central Kalimantan, Indonesia, from 1973 to 2005. International Journal of Wildland Fire, 20(4), 578588. doi: 10.1071/WF10029.

Indriyanto. (2006). Ekologi hutan. Jakarta: Bumi Aksara.

Jayakumar, R., \& Nair, K. K. N. (2013). Species diversity and tree regeneration patterns in tropical forests of the Western Ghats, India. International Scholarly Research Notices Ecology 2013(6), 114. doi: 10.1155/2013/890862.

Khaine, I. K., Woo, S. Y., Kwak, M. J., Lee, S. H., Je, S. M., You, H., \& Kim, J. (2018). Factors affecting natural regeneration of tropical forests across a precipitation gradient in Myanmar. Forest, 9(143), 117. doi:10.3390/f9030143.

Khumbongmayun, A. D., Khan, M. L., \& Tripathi, R. S. (2005). Sacred groves of Manipur, Northeast India: Biodiversity value, status and strategies for their conservation. Biodiversity and Conservation, 14, 1541-1582. doi: 10.1007/s10531-004-0530-5.

Liira, J., Sepp, T., \& Kohv, K. (2011). The ecology of tree regeneration in mature and old forests: Combined knowledge for sustainable forest management. Journal of Forest Research, 16(3), 184-193. doi: 10.1007/s10310-011-0257-6.

Magurran, A. E. (2013). Measuring biological diversity. Oxford: Blackwell Publishing.

Mawazin., \& Subiakto, A. (2013). Keanekaragaman dan komposisi jenis permudaan alam hutan rawa gambut bekas tebangan di Riau. Forest Rehabilitation Journal, 1(1), 59-73. doi: 10.9868/ifrj.1.1.59-73.

Miettinen, J., \& Liew, S. C. (2010). Degradation and development of peatlands in Peninsular Malaysia and in the islands of Sumatra and Borneo since 1990. Land Degradation and Development, 21(3), 285-296. doi: 10.1002/ldr.976.

Miettinen, J., Hooijer, A., Vernimmen, R., Liew, S. C., \& Page, S. E. (2017). From carbon sink to carbon source: Extensive peat oxidation in insular Southeast Asia since 1990. Environmental Research Letters, 12(2), $024014 . \quad$ doi: 10.1088/1748-9326/aa5b6f.

Odum, E. P. (1996). Dasar-dasar ekologi (T. Samingan, Terjemahan). Yogyakarta: Gadjah Mada University Press.

Page, S. E., Rieley, J. O., \& Banks, C. J. (2011). Global and regional importance of the tropical peatland carbon pool. Global Change of Biology, 17(2), 798818 . doi: $\quad 10.1111 / \mathrm{j} .1365-$ 2486.2010.02279.x

Pickup, M., Wilson, S., Freudenberger, D., Nicholls, N., \& Gould, L. (2013). Postfire recovery of revegetated woodland communities in South-Eastern Australia. Australian Ecology, 38(3), 300-312. doi: 10.1111/j.14429993.2012.02404.x

Posa, M. R. C., Wijedasa, L. S., \& Corlett, R. T. (2011). Biodiversity and conservation of tropical peat swamp forests. BioScience, 61(1), 49-57. doi: 10.1525/bio.2011.61.

Putra, C. A. S., Manuri, S., Hariyanto., \& Sibaragiang, G. (2011). Pohon-pohon Hutan Alam Rawa Gambut Merang. Palembang: Merang REDD Pilot Project, German International Cooperation-GIZ.

Rachmanadi, D., Faridah, E., Sumardi., \& Van der Meer, P. (2017). Keanekaragaman 
potensi regenerasi vegetasi pada hutan rawa gambut: Studi kasus di Kawasan Hutan Dengan Tujuan Khusus (KHDTK) Tumbang Nusa, Kalimantan Tengah. Jurnal Ilmu Kehutanan 11(2), 224-238. doi: 10.22146/jik.28286.

Rahman, M. R., Rahman, M. M., \& Chowdhury, M. A. (2019). Assessment of natural regeneration status: The case of Durgapur hill forest, Netrokona, Bangladesh. Geology, Ecology, and Landscapes, 4(2), 121-130. doi: 10.1080/24749508.2019.1600911.

Smith, D. M., Larson, B. C., Kelty, M. J., \& Ashton, P. M. S. (1997) The practice of silviculture: Applied forest ecology. New York: John Wiley and Sons.

Tamin, R. P., Ulfa, M., \& Saleh, Z. (2018). Komunitas tumbuhan pada habitat kantong semar (Nepenthes spp.) Taman Hutan Raya Sekitar Tanjung pasca kebakaran hutan. Jurnal Ilmiah Ilmu Terapan Universitas Jambi, 2(2),25-31. doi: 10.22437/jiituj.v2i1.5646.

Tamin, R. P., Ulfa, M., \& Saleh, Z. (2019). Identifikasi potensi pohon induk pada tegakan tinggal Taman Hutan Raya
Orang Kayo Hitam pasca kebakaran hutan. Jurnal Ilmiah Ilmu Terapan Universitas Jambi, 3(1), 10-17. doi: 10.22437/jiituj.v3i1.7337.

Wibisono, I. T. C., \& Dohong, A. (2017). Panduan teknis revegetasi lahan gambut. Jakarta: Badan Restorasi Gambut (BRG) Republik Indonesia.

Wijedasa, L. S., Vernimmen, R., Page, S. E., Muyadi, D., Bahrie, S., Randi, A., \& Hooijer, A. (2020). Distance to forest, mammal and bird dispersal drive natural regeneration on degraded tropical peatland. Forest Ecology and Management, 461, 1-10. doi: 10.1016/j.foreco.2020.117868.

Wulan, A. J., \& Subagio, S. (2016). Efek asap kebakaran hutan terhadap gambaran histologis saluran pernapasan. Majority, 5(3), 162-167.

Yang, X., Yan, D., \& Liu, C. (2014) Natural regeneration of trees in three types of afforested stands in the Taihang Mountains, China. PLoS ONE 9(9), e108744.

doi:10.1371/journal.pone.0108744. 